\title{
Opłata uzdrowiskowa a pobyt w szpitalu uzdrowiskowym - uwagi na tle interpretacji ogólnej ministra finansów
}

\section{Health-resort fee and a stay in a health-resort hospital - comments based on the general interpretation of the Minister of Finance}

Streszczenie. W publikacji przedstawiono argumentację Ministra Finansów zawartą w interpretacji ogólnej z dnia 3 października 2014 r., dotyczącej wykładni art. 17 ust. 2 pkt 2 ustawy o podatkach i opłatach lokalnych. Wskazano, co rozumiano pod pojęciem „szpital” przed 3 października 2014 r. i co w tym zakresie zmieniła interpretacja ogólna Ministra Finansów. Podkreślono, że aktualnie opłata uzdrowiskowa nie powinna być pobierana za pobyt osób fizycznych w szpitalach uzdrowiskowych.

Słowa kluczowe: opłata uzdrowiskowa; interpretacja ogólna; szpital; szpital uzdrowiskowy.

Abstract. The publication presents the argumentation of the Minister of Finance
included in the general interpretation of 3 October 2014 concerning the interpre- 
tation of Article 17 paragraph 2 clause 2 of the Act on Local Taxes and Fees. It was explained what was understood by the term "hospital” before 3 October 2014 and what changed in this subject after the general interpretation of the Minister of Finance was issued. It was emphasized that now the health-resort fee should not be charged from legal persons staying in health resort hospitals.

Keywords: health-resort fee; general interpretation; hospital; heath-resort hospital.

\section{Wprowadzenie}

Zgodnie z art. 17 ust. 2 pkt 2 ustawy z dnia 12 stycznia 1991 r. o podatkach i opłatach lokalnych ${ }^{1}$ opłaty miejscowej oraz uzdrowiskowej nie pobiera się od osób przebywających w szpitalach. Od wielu lat toczą się spory, czy pod pojęciem „szpital” należy rozumieć także „szpital uzdrowiskowy”. W praktyce cezury czasowe w zakresie omawianego problemu wyznaczają dwie daty: 1 lipca 2011 r. i 3 października 2014 r.

1 lipca 2011 r. to data wejścia w życie ustawy z dnia 15 kwietnia 2011 r. o działalności leczniczej ${ }^{2}$ - wobec uchylenia ustawy dotyczącej zakładów opieki zdrowotnej ${ }^{3}$ część organów podatkowych uznała, że dotychczasowa interpretacja pojęcia „szpital” uległa dezaktualizacji ${ }^{4}$. Z kolei 3 października 2014 r. to data wydania przez Ministra Finansów interpretacji ogólnej w zakresie braku obowiązku pobierania opłaty uzdrowiskowej od osób przebywających w szpitalach uzdrowiskowych.

Celem opracowania jest przedstawienie argumentacji użytej w interpretacji ogólnej i jej ocena, a także wskazanie, czy działanie Ministra Finansów ujednoliciło stosowanie przez organy podatkowe przepisów ustawy o podatkach i opłatach lokalnych w zakresie niepobierania opłaty uzdrowiskowej od osób przebywających w szpitalach uzdrowiskowych oraz czy miało wpływ na poglądy doktryny i judykaturę.

\footnotetext{
Tekst jedn. Dz.U. z 2014 r. poz. 849 ze zm., dalej: u.p.o.l.

Tekst jedn. Dz.U. z 2015 r. poz. 618 ze zm.

Ustawa z dnia 30 sierpnia 1991 r. o zakładach opieki zdrowotnej (tekst jedn. Dz.U. 2007 r. nr 14, poz. 89 ze zm.).

4 Zob. szerzej - J. Wantoch-Rekowski, Zwolnienie z opłaty uzdrowiskowej a pobyt w szpitalu uzdrowiskowym, „Przegląd Podatków Lokalnych i Finansów Samorządowych” 2013, nr 7, s. 6-8.
} 


\section{Stanowisko doktryny z lat 2011-2014}

Stanowisko doktryny z lat 2011-2014 (oraz powoływanego przez autorów orzecznictwa) nie było jednolite. $Z$ jednej strony wskazywano, że szpitale uzdrowiskowe to zupełnie inny podmiot niż ten, który został uregulowany w art. 17 ust. 2 pkt 2 u.p.o.l., z drugiej zaś, że pojęcie szpital oznacza nie tylko „zwykły” szpital, ale i szpital uzdrowiskowy.

Pierwsze stanowisko prezentowali m.in. T. Wołowiec i D. Reśko, którzy pisali, że „Ustawodawca jednoznacznie unormował, że zwolniony z opłaty uzdrowiskowej i miejscowej jest pobyt w szpitalu, a nie w szpitalu uzdrowiskowym będącym całkowicie odmienną kategorią zakładu leczniczego, mianowicie - zakładem lecznictwa uzdrowiskowego. Prawo podatkowe musi być interpretowane ściśle. Wszelka wykładnia rozszerzająca przepisów prawa podatkowego jest niedopuszczalna. Jeśli więc ustawodawca zwolnił z opłaty uzdrowiskowej osoby przebywające w szpitalu, to oznacza dokładnie to, co jest w przepisie, czyli szpital, a nie szpital uzdrowiskowy" . Bardzo podobnie stanowisko prezentował w samodzielnej publikacji T. Wołowiec, który w glosie do wyroku WSA wskazywał, że „Zwalniając w ustawie podatkowej z opłaty uzdrowiskowej osoby przebywające w szpitalach, ustawodawca nie miał na myśli osób przebywających w zakładach lecznictwa uzdrowiskowego, jakkolwiek by się one nie nazywały. Pojęcie «szpital», zawarte w art. 17 ust. 2 pkt 2 u.p.o.l., to nie sama nazwa, lecz treść jaką ze sobą niesie. W sytuacji gdy treść ową można już jednoznacznie odczytać z definicji utworzonej przez ustawodawcę w ustawie o działalności leczniczej, nadawanie temu pojęciu treści wychodzących poza granice definicji szpitala jest niedopuszczalną, w świetle prawa podatkowego, wykładnią rozszerzającą"6.

Z drugiej z kolei strony wskazywano, że pojęcie szpital powinno być interpretowane na podstawie zarówno ustawy z dnia 15 kwietnia $2011 \mathrm{r}$. o działalności leczniczej, jak i ustawy z dnia 28 lipca 2005 r. o lecznictwie uzdrowiskowym, uzdrowiskach i obszarach ochrony uzdrowiskowej oraz

5 T. Wołowiec, D. Reśko, Pobór opłaty uzdrowiskowej w szpitalach uzdrowiskowych, „Finanse Komunalne” 2013, nr 10, s. 73.

6 T. Wołowiec, Glosa do wyroku WSA w Szczecinie z dnia 14 marca 2013 r. (II SA/Sz 921/12), „Glosa” 2013, nr 4, s. 34-35. 
o gminach uzdrowiskowych ${ }^{7}$. „Szpitale uzdrowiskowe stanowią istotne uzupełnienie szpitali «zwykłych». Zasadne jest więc stanowisko, że usta-

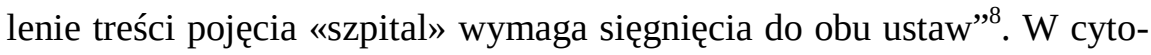
wanej publikacji wskazano także, że „Uzasadnione wydaje się być przyjęcie, że decydująca powinna być wykładnia językowa pojęcia «szpital», która jest nie tylko punktem wyjścia wykładni prawa, ale także zakreśla jej granice.” Według autora „W znaczeniu słownikowym szpital to «zamknięty zakład opieki zdrowotnej, przeznaczony dla ciężko chorych» ${ }^{9}$. Definicja słownikowa uzupełniona jest wskazaniem kilku rodzajów szpitali, tj. miejski, wojewódzki, wojskowy, polowy. Przykładowo można wskazać na używane powszechnie inne przymiotnikowe dookreślenia szpitali, tj. powiatowy, uniwersytecki, zakaźny czy właśnie uzdrowiskowy”10.

\section{Interpretacja ogólna Ministra Finansów z dnia 3 października 2014 r.}

W celu zapewnienia jednolitego stosowania przez wójtów, burmistrzów oraz prezydentów miast prawa podatkowego w zakresie niepobierania opłaty uzdrowiskowej od osób przebywających w szpitalach uzdrowiskowych, Minister Finansów wydał 3 października 2014 r. interpretację ogólną ${ }^{11}$. Podstawę prawną do wydania interpretacji ogólnej stanowi art. 14a $\S 1$ ustawy z dnia 29 sierpnia 1997 r. - Ordynacja podatkowa ${ }^{12}$, zgodnie z którym minister właściwy do spraw finansów publicznych dąży do zapewnienia jednolitego stosowania przepisów prawa podatkowego przez organy podatkowe oraz organy kontroli skarbowej, dokonując w szczególności ich interpretacji, z urzędu lub na wniosek, przy uwzględnieniu orzecznictwa sądów oraz Trybunału Konstytucyjnego lub Europejskiego Trybunału Sprawiedliwości (interpretacje ogólne). W literaturze wskazuje

\footnotetext{
Tekst jedn. Dz.U. z 2012 r. poz. 651 ze zm.

J. Wantoch-Rekowski, Zwolnienie ..., s. 9.

E. Sobol (red.), Mały słownik języka polskiego, Warszawa 1995, s. 913.

J. Wantoch-Rekowski, Zwolnienie ..., s. 9.

Dz.Urz. MF z 2014 r. poz. 38.

Tekst jedn. Dz.U. z 2015 r. poz. 613 ze zm.
} 
się, że interpretacja ogólna prawa podatkowego dokonywana przez Ministra Finansów ma charakter generalny, a także że zawiera postanowienia ogólne i abstrakcyjne, ale nie daje to jakichkolwiek podstaw do zaliczenia jej do źródeł prawa podatkowego ${ }^{13}$.

Minister Finansów, odnosząc się do przyczyn uzasadniających wydanie interpretacji ogólnej, wskazywał, że w praktyce powstała wątpliwość, czy zakres zwolnienia określony w art. 17 ust. 2 pkt 2 ustawy o podatkach i opłatach lokalnych obejmuje osoby przebywające w szpitalach uzdrowiskowych.

W interpretacji słusznie wskazano, że ustawa o podatkach i opłatach lokalnych nie zawiera definicji „szpitala”, a definicję taką zawiera ustawa o działalności leczniczej, zgodnie z którą pod pojęciem „szpital” trzeba rozumieć przedsiębiorstwo podmiotu leczniczego, w którym podmiot ten wykonuje działalność leczniczą. W dalszej części interpretacji Minister Finansów analizował pojęcie „szpital uzdrowiskowy” na płaszczyźnie wynikającej z ustawy z dnia 28 lipca 2005 r. o lecznictwie uzdrowiskowym, uzdrowiskach i obszarach ochrony uzdrowiskowej oraz o gminach uzdrowiskowych i doszedł do wniosku, że zgodnie ze wskazanymi przepisami w szpitalu uzdrowiskowym wykonywana jest działalność lecznicza w rodzaju stacjonarne i całodobowe świadczenia szpitalne, a tym samym szpital uzdrowiskowy jest jednym z rodzajów szpitali w rozumieniu ustawy o działalności leczniczej.

Minister Finansów wyraźnie wskazał, że „Artykuł 17 ust. 2 pkt 2 ustawy o podatkach i opłatach lokalnych, określający zakres podmiotowy wyłączenia z obowiązku uiszczenia opłaty uzdrowiskowej, nie zawiera wyjątku dla osób przebywających w szpitalach uzdrowiskowych. Ustawodawca nie rozróżnił, w celu korzystania z wyłączenia od tej opłaty, osób przebywających w szpitalach uzdrowiskowych i w innych szpitalach”. W końcowej części interpretacji Minister Finansów słuszne wskazał: „Sumując, należy stwierdzić, iż na podstawie art. 17 ust. 2 pkt 2 ustawy o podatkach i opłatach lokalnych od osób przebywających w szpitalach uzdrowiskowych nie pobiera się opłaty uzdrowiskowej”.

13 R. Mastalski [w:] B. Adamiak, J. Borkowski, R. Mastalski, J. Zubrzycki, Ordynacja podatkowa - Komentarz 2014, Wrocław 2014, s. 135. 


\section{Poglądy doktryny i stanowisko judykatury po 3 października 2014 r.}

Wydawać by się mogło, że interpretacja Ministra Finansów powinna spowodować ujednolicenie stosowania art. 17 ust. 2 pkt 2 ustawy o podatkach i opłatach lokalnych w zakresie zwolnienia osób przebywających w szpitalach uzdrowiskowych. Tak się jednak do końca nie stało. Można wskazać na (nieliczne wprawdzie) stanowiska organów podatkowych, które „nie zauważyły” interpretacji i uznawały, że zwolnienie wskazane w ww. przepisie nie dotyczy szpitali uzdrowiskowych ${ }^{14}$. Również można spotkać poglądy przedstawicieli doktryny, dla których interpretacja Ministra Finansów nic nie zmieniła. Przykładowo T. Wołowiec pisał, że „Pojęcie «szpital» zawarte w art. 17 ust. 2 pkt. 2 u.p.o.l., to nie sama nazwa, lecz treść jaką ze sobą niesie. Nadawanie natomiast temu pojęciu treści wychodzących poza granice definicji szpitala wydaje się być niedopuszczalną na gruncie prawa podatkowego wykładnią rozszerzającą, bowiem prawo to musi być ściśle interpretowane. Skoro zatem ustawodawca zwolnił z opłaty uzdrowiskowej osoby przebywające w szpitalach, to oznacza to, co jest w przepisie, czyli szpital, a nie szpital uzdrowiskowy”.

Stosunkowo niedawno T. Wołowiec ponownie zajął się problematyką dotyczącą interpretacji pojęcia „szpital”"16. Trudno jednakże z całą pewnością stwierdzić, czy autor akceptuje wykładnię dokonaną przez Ministra Finansów w interpretacji ogólnej. W pierwszym punkcie artykułu stwierdza, że „szpitalem, o którym mowa w przepisach podatkowych, jest przedsiębiorstwo, w którym udzielane są świadczenia szpitalne, w odróżnieniu od zakładu lecznictwa uzdrowiskowego o nazwie «szpital uzdrowiskowy», w którym udzielane są stacjonarne i całodobowe świad-

14 Np. decyzja organu podatkowego z dnia 4 listopada 2014 r. - zob. wyrok WSA w Szczecinie z dnia 14 maja 2015 r., I SA/Sz 363/15, LEX nr 1759869.

15 T. Wołowiec, Glosa do wyroku WSA w Szczecinie z dnia 15 maja 2014 r. (I SA/Sz 1512/13), „Przegląd Orzecznictwa Podatkowego” 2014, nr 6, s. 520; autor zauważył jednak fakt wydania interpretacji, czyniąc o tym wzmiankę w przypisie (s. 514).

16 T. Wołowiec, Pobyt w szpitalu uzdrowiskowym a obowiqzek poboru opłaty uzdrowiskowej, „Przegląd Prawa Publicznego” 2016, nr 1, s. 64-73. 
czenia zdrowotne inne niż świadczenia szpitalne”17. W punkcie piątym można przeczytać, że „Skoro zatem ustawodawca zwolnił z opłaty uzdrowiskowej osoby przebywające w szpitalach, to oznacza to, że co jest w przepisie, czyli szpital, a nie szpital uzdrowiskowy”" ${ }^{\prime 1}$. Natomiast w części końcowej opracowania („Wnioski”) wskazuje, że „Nie ma podstaw do różnicowania na gruncie ustawy o podatkach i opłatach lokalnych szpitali w ujęciu ogólnym i innych szpitali o charakterze specjalistycznym, w tym od szpitali uzdrowiskowych, skoro zakres regulacji w obu przypadkach jest samoistny” ${ }^{19}$ oraz w ostatnim zdaniu artykułu - „Wynika z powyższego, że ustawa o podatkach i opłatach lokalnych w celu wyłączenia z obowiązku uiszczenia opłaty uzdrowiskowej nie różnicuje osób przebywających w szpitalach ze względu na cel pobytu i rodzaj pobieranych świadczeń”,20. Warto również wskazać, że T. Wołowiec i w tej publikacji „zauważa” interpretację ogólną Ministra Finansów, ale poświęca jej niewiele miejsca (końcowa część „Wniosków”)"

Wykładnia zaprezentowana w interpretacji Ministra Finansów została zaakceptowana przez judykaturę. Spośród wielu orzeczeń warto wskazać na kilka. I tak WSA w Szczecinie w wyroku z dnia 18 marca 2015 r. ${ }^{22}$ wskazał, że skoro ustawodawca w art. 17 ust. 2 pkt 2 nie dokonał zróżnicowania typów szpitali, oznacza to, że zwolnienie ma zastosowanie również do pacjentów szpitali uzdrowiskowych. Podobnie orzekł tenże WSA w wyroku z dnia 14 maja 2015 r. ${ }^{23}$, w którym dodatkowo w uzasadnieniu zwrócono uwagę, że w celu zapewnienia jednolitego stosowania prawa podatkowego Minister Finansów wydał interpretację w sprawie niepobierania opłaty uzdrowiskowej od osób przebywających w szpitalach uzdrowiskowych.

Również Naczelny Sąd Administracyjny prezentuje wykładnię przyjętą przez Ministra Finansów w interpretacji ogólnej. Przykładowo można

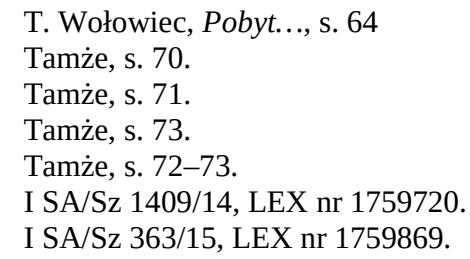


wskazać, że w wyroku z dnia 24 września 2015 r. ${ }^{24}$ stwierdził, że „brak jest uzasadnionych podstaw do przyjęcia, że użyte w art. 17 ust. 2 pkt 2 ustawy o podatkach i opłatach lokalnych określenie «szpital» oznacza wyłącznie «szpital» w rozumieniu art. 2 pkt 9 ustawy o działalności leczniczej i nie obejmuje tych podmiotów, które w innych ustawach określane są tym słowem. Nie można zatem uznać za uzasadniony, również w kontekście przepisów art. 2 ust. 1 pkt 9, 11, 12 ustawy o działalności leczniczej i art. 2 pkt 10 ustawy o lecznictwie uzdrowiskowym, zarzutu skargi kasacyjnej, że Sąd pierwszej instancji dokonał błędnej wykładni wymienionego wyżej przepisu ustawy podatkowej, ani uznać tej wykładni za niedopuszczalną rozszerzającą wykładnię przepisu prawa przewidującego zwolnienie podatkowe”.

\section{Podsumowanie}

Nie ulega wątpliwości, że interpretacja ogólna Ministra Finansów z 3 października 2014 r. jest prawidłowa i przekonująca. Większość argumentów, które wykorzystał Minister Finansów, było wcześniej prezentowanych w doktrynie ${ }^{25}$.

Wprawdzie można jeszcze spotkać stanowiska odmienne niż zaprezentowane w interpretacji, tak organów podatkowych, jak przedstawicieli doktryny, to uznać je należy za odosobnione. Ponadto, co do zasady jednolita linia orzecznicza sądów administracyjnych nie pozostawia wątpliwości i w jej świetle zwolnieniu, uregulowanemu w art. 17 ust. 2 pkt 2, podlegają także osoby przebywające w szpitalach uzdrowiskowych.

Niewątpliwie interpretacja Ministra Finansów z 3 października 2014 r. przyczyniła się w znacznym stopniu do niemalże jednolitej wykładni art. 17 ust. 2 pkt 2 u.p.o.l. (w kontekście szpitali uzdrowiskowych) przez organy podatkowe, judykaturę i doktrynę. Pojawiające się sporadycznie odmienne sposoby wykładni tego przepisu nie umniejszają znaczenia, jakie dla praktyki wywarła interpretacja Ministra Finansów.

24 II FSK 1781/13, Legalis nr 1362560.

25 Np. J. Wantoch-Rekowski, Zwolnienie ..., s. 6-9. 
Opłata uzdrowiskowa a pobyt w szpitalu uzdrowiskowym...

\section{Bibliografia:}

Mastalski R. [w:] B. Adamiak, J. Borkowski, R. Mastalski, J. Zubrzycki, Ordynacja podatkowa - Komentarz 2014, Oficyna Wydawnicza „Unimex”, Wrocław 2014.

Sobol E. (red.), Mały słownik języka polskiego, PWN, Warszawa 1995.

Wantoch-Rekowski J., Zwolnienie z opłaty uzdrowiskowej a pobyt $w$ szpitalu uzdrowiskowym, „Przegląd Podatków Lokalnych i Finansów Samorządowych” 2013, nr 7, s. 6-9.

Wołowiec T., Glosa do wyroku WSA w Szczecinie z dnia 14 marca 2013 r. (II SA/Sz 921/12), „Glosa” 2013, nr 4, s. 29-35.

Wołowiec T., Glosa do wyroku WSA w Szczecinie z dnia 15 maja 2014 r. (I SA/Sz 1512/13), „Przegląd Orzecznictwa Podatkowego” 2014, nr 6, s. 514-520.

Wołowiec T., Pobyt w szpitalu uzdrowiskowym a obowiq̨zek poboru opłaty uzdrowiskowej, „Przegląd Prawa Publicznego” 2016, nr 1, s. 64-73.

Wołowiec, D. Reśko, Pobór opłaty uzdrowiskowej w szpitalach uzdrowiskowych, „Finanse Komunalne” 2013, nr 10, s. 70-73. 